\title{
Front Matter: Volume 11086
}

, "Front Matter: Volume 11086," Proc. SPIE 11086, UV and Higher Energy Photonics: From Materials to Applications 2019, 1108601 (30 September 2019); doi: $10.1117 / 12.2552594$

SPIE Event: SPIE Nanoscience + Engineering, 2019, San Diego, California, United SPIE. States 


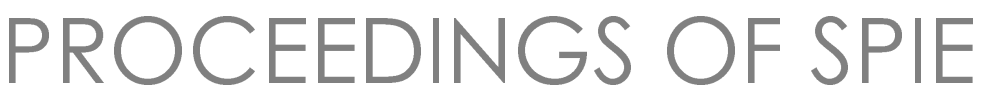

\title{
UV and Higher Energy Photonics: From Materials to Applications 2019
}

\author{
Gilles Lérondel \\ Yong-Hoon Cho \\ Atsushi Taguchi \\ Satoshi Kawata \\ Editors
}

11-13 August 2019

San Diego, California, United States

Sponsored and Published by

SPIE 
The papers in this volume were part of the technical conference cited on the cover and title page. Papers were selected and subject to review by the editors and conference program committee. Some conference presentations may not be available for publication. Additional papers and presentation recordings may be available online in the SPIE Digital Library at SPIEDigitalLibrary.org.

The papers reflect the work and thoughts of the authors and are published herein as submitted. The publisher is not responsible for the validity of the information or for any outcomes resulting from reliance thereon.

Please use the following format to cite material from these proceedings:

Author(s), "Title of Paper," in UV and Higher Energy Photonics: From Materials to Applications 2019, edited by Gilles Lérondel, Yong-Hoon Cho, Atsushi Taguchi, Satoshi Kawata, Proceedings of SPIE Vol. 11086 (SPIE, Bellingham, WA, 2019) Seven-digit Article CID Number.

ISSN: 0277-786X

ISSN: 1996-756X (electronic)

ISBN: 9781510628656

ISBN: 9781510628663 (electronic)

Published by

SPIE

P.O. Box 10, Bellingham, Washington 98227-0010 USA

Telephone +13606763290 (Pacific Time) · Fax +1 3606471445

SPIE.org

Copyright @ 2019, Society of Photo-Optical Instrumentation Engineers.

Copying of material in this book for internal or personal use, or for the internal or personal use of specific clients, beyond the fair use provisions granted by the U.S. Copyright Law is authorized by SPIE subject to payment of copying fees. The Transactional Reporting Service base fee for this volume is $\$ 21.00$ per article (or portion thereof), which should be paid directly to the Copyright Clearance Center (CCC), 222 Rosewood Drive, Danvers, MA 01923. Payment may also be made electronically through CCC Online at copyright.com. Other copying for republication, resale, advertising or promotion, or any form of systematic or multiple reproduction of any material in this book is prohibited except with permission in writing from the publisher. The CCC fee code is 0277$786 \times / 19 / \$ 21.00$.

Printed in the United States of America by Curran Associates, Inc., under license from SPIE.

Publication of record for individual papers is online in the SPIE Digital Library.

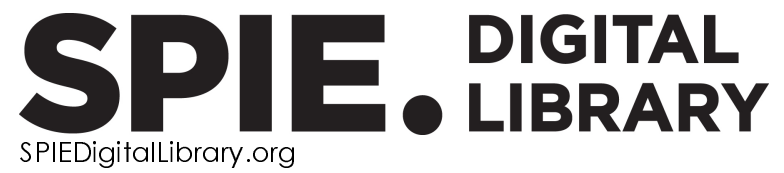

Paper Numbering: Proceedings of SPIE follow an e-First publication model. A unique citation identifier (CID) number is assigned to each article at the time of publication. Utilization of CIDs allows articles to be fully citable as soon as they are published online, and connects the same identifier to all online and print versions of the publication. SPIE uses a seven-digit CID article numbering system structured as follows:

- The first five digits correspond to the SPIE volume number.

- The last two digits indicate publication order within the volume using a Base 36 numbering system employing both numerals and letters. These two-number sets start with $00,01,02,03,04$, 05, 06, 07, 08, 09, OA, OB ... 0Z, followed by 10-1Z, 20-2Z, etc. The CID Number appears on each page of the manuscript. 


\section{Contents}

$\checkmark \quad$ Authors

vii Conference Committee

RAMAN AND ATR SPECTROSCOPY I

$1108604 \quad$ Far- and deep-ultraviolet spectroscopy applied for ionic liquids (Invited Paper) [1 1086-3]

1108605 Tunable deep-UV Raman spectroscopy reveals nitrate photolysis [1 1086-4]

MATERIALS AND DEVICES

11086 OC III-nitride emitters and detectors for UV optoelectronic applications grown by metalorganic chemical vapor deposition (Invited Paper) [1 1086-41]

RAMAN AND ATR SPECTROSCOPY II

11086 ON Frontiers of UV resonant Raman spectroscopy by using synchrotron radiation: the case of aqueous solvation of model peptides (Invited Paper) [1 1086-21]

$110860 Q \quad$ Conformational stability of DNA in hydrated ionic liquid by synchrotron-based UV resonance Raman [1 1086-24]

\section{DUV MICROSCOPY AND NANOSCOPY}

11086 OU UV illumination for electron and ion beam microscopy and nanofabrication [1 1086-28]

\section{DUV PLASMONICS II}

11086 OX UV-LED activated semiconductor sensors with tailored structure (Invited Paper) [1 1086-40]

11086 OZ Large available volume particles for enhanced deep UV local Raman sensing [1 1086-32] 
Proc. of SPIE Vol. 11086 1108601-4

\section{Downloaded From: https://www.spiedigitallibrary.org/conference-proceedings-of-spie on 25 Apr 2023
Terms of Use: https://www.spiedigitallibrary.org/terms-of-use}




\section{Authors}

Numbers in the index correspond to the last two digits of the seven-digit citation identifier (CID) article numbering system used in Proceedings of SPIE. The first five digits reflect the volume number. Base 36 numbering is employed for the last two digits and indicates the order of articles within the volume. Numbers start with 00, 01, 02, 03, 04, 05, 06, 07, 08, 09, 0A, 0B...0Z, followed by 10-12, 20-2Z, etc.

Adeli, Babak, OX

Bakhtiary-Noodeh, Marzieh, OC

Bleiner, D., 05

Borgschulte, A., 05

Bottari, Cettina, ON, OQ

Catalini, Sara, ON

Chen, Ping, OC

Detchprohm, Theeradetch, OC

Dupuis, Russell D., OC

Espid, Ehsan, OX

Fernandez Bravo, Angel, $\mathrm{OZ}$

Gessini, Alessandro, ON, OQ

Hallen, Hans D., $\mathrm{OZ}$

Jeong, Hoon, OC

$\mathrm{Ji}, \mathrm{Mi}-\mathrm{Hee}, \mathrm{OC}$

Juodkazis, Saulius, OU

Katkus, Tomas, OU

Le, Nguyen Hoai An, oU

Lim, Shuang Fang, $\mathrm{OZ}$

Mancini, I., OQ

Masciovecchio, Claudio, $\mathrm{ON}, 0 \mathrm{Q}$

Mehta, Karan, OC

Mele, A., OQ

Morikawa, Junko, oU

$\mathrm{Ng}$, Soon Hock, OU

Rossi, Barbara, ON, OQ

Ryu, Meguya, oU

Sambalova, O., 05

Schneider, U., 05

Schuck, Peter James, $\mathrm{OZ}$

Seniutinas, Gediminas, OU

Shen, Shyh-Chiang, OC

Sterzi, A., 05

Stoddart, Paul, OU

Taghipour, Fariborz, OX

Tanabe, Ichiro, 04

Tsou, Chuan-Wei, OC

Wirth, Janina, $\mathrm{OZ}$

Yoder, P. Douglas, OC 
Proc. of SPIE Vol. 11086 1108601-6 Downloaded From: https://www.spiedigitallibrary.org/conference-proceedings-of-spie on 25 Apr 2023
Terms of Use: https://www.spiedigitallibrary.org/terms-of-use 


\title{
Conference Committee
}

\author{
Symposium Chairs
}

Halina Rubinsztein-Dunlop, The University of Queensland (Australia)

Mark L. Brongersma, Geballe Laboratory for Advanced Materials

(GLAM) (United States), Stanford University (United States)

Symposium Co-chairs

Reuven Gordon, University of Victoria (Canada)

Natalia M. Litchinitser, Duke University (United States)

Conference Chairs

Gilles Lérondel, Université de Technologie de Troyes (France)

Yong-Hoon Cho, KAIST (Korea, Republic of)

Atsushi Taguchi, Osaka University (Japan)

Conference Co-chair

Satoshi Kawata, Osaka University (Japan)

Conference Program Committee

Sanford A. Asher, University of Pittsburgh (United States)

Steve Blair, The University of Utah (United States)

Zhanghai Chen, Fudan University (China)

Yasin Ekinci, Paul Scherrer Institut (Switzerland)

Torsten Frosch, Leibniz-Institut für Photonische Technologien e.V.

(Germany)

Naomi J. Halas, Rice University (United States)

Hans D. Hallen, North Carolina State University (United States)

Chennupati Jagadish, The Australian National University (Australia)

Junyong Kang, Xiamen University (China)

Yoichi Kawakami, Kyoto University (Japan)

Jong Kyu Kim, Pohang University of Science and Technology

(Korea, Republic of)

Yasuaki Kumamoto, Kyoto Prefectural University of Medicine (Japan)

Paul T. Matsudaira, National University of Singapore (Singapore)

Eva Monroy, CEA Grenoble (France)

Fernando Moreno, Universidad de Cantabria (Spain)

Yukihiro Ozaki, Kwansei Gakuin University (Japan)

Sung-Jin Park, University of Illinois (United States)

Jérôme Plain, Université de Technologie de Troyes (France) 
Remo Proietti Zaccaria, Istituto Italiano di Tecnologia (Italy) Olivier Soppera, Université de Haute Alsace (France)

\section{Session Chairs}

1 Raman and ATR Spectroscopy I

Atsushi Taguchi, Osaka University (Japan)

2 DUV Plasmonics |

Atsushi Taguchi, Osaka University (Japan)

3 Materials and Devices

Gilles Lérondel, Université de Technologie Troyes (France)

4 Deep-UV LEDs

Yong-Hoon Cho, KAIST (Korea, Republic of)

$5 \quad$ Photochemistry and Nanofabrications

Serhiy Danylyuk, Rheinisch-Westfälische Technische Hochschule Aachen (Germany)

6 Raman and ATR Spectroscopy II

Yukihiro Ozaki, Kwansei Gakuin University (Japan)

7 DUV Microscopy and Nanoscopy

Satoshi Kawata, Osaka University (Japan)

8 DUV Plasmonics II

Atsushi Ono, Shizuoka University (Japan) 